\title{
Branding and selling a country through translated tourism advertising: Spain's image
}

\author{
Adrián Fuentes Luque ${ }^{1}$ \\ Universidad Pablo de Olavide
}

\begin{abstract}
Countries and territories willing to market and sell their products and services abroad do their best to identify them with a defined, specific image or identity, a brand. However, choosing the appropriate one sometimes proves to be a confusing task. Spain is probably one of the best examples, facing problems such as stereotypes, a poor strategic vision and a lack of knowledge of what is expected, and how it is really perceived. Translators are a key figure in this process. As mediators, they are not merely linguistic experts (Fuentes \& Kelly, 2000), but intercultural analysts, who should take active part in the proces's of building the image or brand of a country. The branding and selling of the country often depends on the translator to enhance the communicative effectiveness of the message. This paper analyses the role image plays in Spain's tourist advertising, and how this has been and is now addressed, illustrating it through a case study of examples from institutional campaigns, reflected on a small-scale reception study among English-speakers aimed at probing the views of tourists.
\end{abstract}

Keywords: advertising, branding, image, reception, tourism, translation

\section{RESUMEN}

Los países y territorios que intentan comercializar sus productos y servicios en el extranjero intentan ofrecer una imagen definida de su identidad, de su marca. No obstante, en ocasiones es difícil dar con la imagen apropiada. España quizá sea uno de los mejores ejemplos: debe enfrentarse a los estereotipos, a una visión estratégica deficiente y a una falta de conocimiento de lo que se espera y cómo se percibe realmente. Los traductores

1 Corresponding author - Universidad Pablo de Olavide, Departamento de Filología y Traducción, Facultad de Humanidades, Crta. de Utrera, km. 1, 41013 Sevilla (Spain).

Email: afuentes@upo.es 
son clave en este proceso. Como mediadores, son mucho más que expertos lingüísticos (Fuentes \& Kelly, 2000); son analistas interculturales, que deben participar activamente en el proceso de construcción de la imagen de una marca o un país, proceso que a menudo depende del traductor para potenciar la eficacia comunicativa del mensaje. Este artículo analiza el papel de la imagen en la publicidad o promoción turística de España, y cómo se ha abordado, ilustrándolo mediante un estudio de caso con ejemplos de campañas institucionales basadas en un estudio de recepción entre turistas de habla inglesa a fin de sondear sus opiniones.

Palabras clave: publicidad, marca, imagen, recepción, turismo, traducción

\section{Introduction}

It is difficult to know how much business is lost to the travel trade by not informing or receiving foreign visitors correctly in their own linguistic and cultural frames of reference. Almost any country willing to market and sell its products and services abroad tries to identify them with a specific image or identity, a brand. But choosing the appropriate one is a risky and sometimes misleading task. Spain is probably one of the best examples, a country which has been the victim of stereotypes, a poor strategic vision and a lack of knowledge of what is expected (Nobs, 2003), and how it is really perceived. The translator's job in this process is of paramount importance. As a mediator, s/he is not merely a linguistic expert (Fuentes \& Kelly, 2000), but an intercultural analyst, who should take active part in the process of forging the image or brand of a country. The branding and selling of the country often depends on the translator, who plays the role of a pathfinder in "enhancing the communicative effectiveness of the message" (Adab, 2000, p. 223).

In the case of Spanish institutional advertising (versus private advertising), there is a rather established image or brand, which is confusingly and somehow randomly applied to other institutional or private advertising campaigns. Translation here seems to be restricted to linguistic equivalence, overlooking basic factors. This paper aims to shed some light on the role image plays in Spain's tourist advertising, and how this has been and is now addressed, with a series of examples.

\section{Tourist texts: behind the scenes}

According to the World Tourist Organization (WTO), the three leading world tourist destinations are: France (over 83 million visitors in 2015), the US (70 million in the same year) and Spain (60.7 million visitors $)^{2}$. In 2014, Spain was 2 nd in tourist 
earnings worldwide (and 1st in Europe) with US\$ 65 billion in 2014. Tourism is Spain's main source of income. This fact places a huge importance on the image of Spain abroad.

Quality tourism requires quality products. As such, there is a need for quality translations of texts that can ensure positive satisfaction levels on the part of the tourist. But what is expected from a quality translator in the translation of tourist texts? If we consider tourism as an export product, then it follows that, as Séguinot (1994) points out, the intercultural competence of the translator (in many different terms) is an essential element in the commercialization of the tourism trade.

According to Kelly (1997b), the tourist text can be classified as anything published by any organization that is designed to either give information to visitors or to advertise a destination and encourage travelling to that destination. The two main functions of a tourist advertising text are informative and persuasive: texts of this kind are intended to provide information about a given destination to potential tourists, and to attract them to a particular destination or event. The variety of texts can be extremely varied. However, I will only deal with tourist advertising texts in this paper, and more particularly, this type of text in relation to the image of the destination country.

There is no doubt that new media, like the Internet, social media, and mobile apps, have opened new possibilities for the development of fresh ways of attracting tourists. Such media also pose new and complex challenges for software developers, marketing and creative teams, and translators, which merit specific studies. In this sense, the characteristics and potential of new forms of text such as dynamic brochures, interactive personalized menus and social media platforms, surely need a more open, interdisciplinary approach, with a strong intercultural component that surpasses the linguistic level.

The tourist sector has undergone a process of diversification over the last few years, and new (sub)types of tourism have emerged: "quality tourism", eco-tourism and rural tourism, and business tourism, to name but a few. This has brought about a whole new array of tourist-related publications, each with a different style, layout and target reader. Given the specific characteristics of the different fields of knowledge involved, each of these areas would merit individual study.

Tourist advertisements demand a combination of textual, iconic and graphic elements. Depending on the medium, the proportion of these elements will vary. Most institutional tourist campaigns use text/graphic advertising on general or specialized written publications, where space is limited. A tourist text is the result of a complex process that includes a heavy load of concentrated marketing, culture and the use of different semiotic and linguistic systems. The translated version 
should follow the same conventions but this is not always the case. As a result, ineffective translations are produced which compromise the objective of the final product.

Marketing has taken over the new technologies and multimedia in the last few years. Most national and regional tourist offices have nowadays entire websites dedicated to tourist destinations. Also, banners purchased by advertisers containing tourism information appear at the top of almost any commercial site. Advertisers are increasingly making use of tools such as pop-up windows, which can cause a negative effect due to their unexpected and annoying presence (especially if they include music or sound), and prevent the translated text from successfully meeting its function and objective.

Stereotypes have a strong tendency to be negative and extremely powerful and long-lasting. In the world of international advertising, the use of stereotypes has become a well-established tool, but sometimes there is a lack of knowledge about the cultural nuances and connotations of stereotypes. The translator can prove tremendously useful in this sense, bridging the intercultural gap.

In 1996, Lamo de Espinosa (1996) carried out a detailed analysis of Spain's image abroad. Later, in 2002, Turespaña, the Spanish Tourist Board, commissioned an indepth survey to find out which were the existing stereotypes about Spain among European citizens (Noya, 2002). The generic image of Spain would be based on three main elements: good weather, sun and beach; tradition and folklore; and the Spanish character (i.e., social, friendly, cheerful, spontaneous and passionate). Different surveys by Noya (2002) also reflected other stereotypes of Spain: Spain is, after Italy and France, the preferred country, with good food and wine, attractive women and men, kind and hospitable people, and is considered an ideal country to live in.

Within the European Union, Spain is seen as a holiday and leisure destination. In the United States there seems to be confusion between "Hispanic" and "Spanish-ness". For those who knew the difference, Spain was seen as a leisure destination, with friendly people possessing a good sense of humour. It is worth mentioning that Americans noted the "uniqueness" of Spain as a positive stereotype. Americans tend to associate Spain with style and distinction more than Europeans. Such confusion seems to persist today, and many people in the US still cannot tell the difference between "Hispanic", “Latino", and "Spanish".

$3 \quad<$ http://www.huffingtonpost.com/entry/difference-between-hispanic-latino-andspanish_us_55a7ec20e4b0c5f0322c9e44> [15/07/2016]. 
In terms of negative stereotypes, one out of three citizens from the European countries surveyed (UK, France, Germany, Italy) would never marry a Spaniard, and one out of ten would never have a Spaniard as a close friend. This figure was higher among US citizens. Spain is also stereotyped as "too traditional", "not very innovative", "low quality" and with a "lack of style". Noya (2002) mentions a recent survey (ESOMAR, 2001) which establishes Italy and Spain (in this order) as the laziest and the least reliable countries in Europe. In general, the British have the worst opinion in Europe about Spanish people, seeing them as unreliable, selfish, rude, weak, authoritarian and, above all, idle. In this vein, I think further research on stereotypes would be desirable after the recent enlargements of the European Union, which now includes most Eastern European countries.

The American Marketing Association defines image as "consumer perception of a product, institution, brand, company or person which may or may not correspond to reality". In this sense, it could be said that "the differentiation of a brand is achieved through the perceived image" (Andreu, Bigné \& Cooper, 2000, p. 49). Three components are normally established in the formation of an image: beliefs and attitudes associated with the product, level of knowledge about the destination, and the expectations created by the product (Nobs, 2003). It is precisely in the last two elements that translation plays a key role. User expectations are frequently overlooked in the creation and translation process of tourist advertising material, resulting in failed promotion campaigns that can damage the image of the destination and the products it offers.

In a detailed study, Fuentes \& Kelly (2000) recognise that the image of Spain abroad is not really the one the country "deserves". Specifically, the British perception of Spain is more negative than the French, the Italian or the German. Spain is a lazy, inefficient, and corrupt country, which is technologically underdeveloped. These findings also coincide with those of Kelly (1997a) in a large corpus study of the discursive construction of Spain in the British press. In addition, there is a lack of knowledge among European consumers and users regarding Spanish products. The opposite occurs with products of other countries: German products are associated with efficiency and state-of-the-art technological development, French products are associated with good taste and glamour, and Italy makes excellent use of its image of style and elegance.

The projected image is "a 'pull' factor in the destination decision process, which is transmitted by communication channels targeted at the potential tourist" (Ashworth, 1991; in Andreu, Bigné \& Cooper, 2000, p. 50). The image projected by a given tourist destination is derived to a great extent from the different advertising campaigns. In the case of Spain, according to Andreu, Bigné \& Cooper (2000, p. 52), during the 1970 s and 80 s there was no coherence in communication strategies for the design 
and creation of promotional material for Spain as a tourist destination. This situation was aggravated by the fact that neither the target audience nor the main features of the target users were clearly defined. From the intercultural mediation point of view, this shows the importance of translation as a key element for successful communication. It is also necessary to establish appropriate feedback mechanisms that will allow for the different participating agents to reassess and fine-tune the elements of the tourist advertising campaign.

The perceived image, on the other hand, is a "dynamic concept on that previous knowledge [the potential tourist has about the destination], the experience at the destination, and the tourist's evaluation of that knowledge will affect his/her image of the destination [sic]" (Hu \& Ritchie, 1993; in Andreu, Bigné \& Cooper, 2000, p. 51). The satisfaction level that results from an evaluation process can help improve the destination image. Since the perceived image is not a static parameter, those involved in tourist advertising should be in constant review of the tourist products offered and the projected image, trying to adjust market niches, products and destinations and existing and potential tourists. In my view, the translation of tourist advertising texts plays a decisive role in this process. Thus, countries like Australia and the UK have developed user-friendly and very attractive institutional tourist websites with different contents, layout and products for different target audiences. This would reflect the importance of appropriately targeting niche markets. Spain's tourist advertising strategy over the last few years would be in the same line.

Brand is defined by Morgan \& Pritchard (2001, p. 15) as "a unique combination of product characteristics and added values, both functional and non-functional, which have taken a relevant meaning which is inextricably linked to that brand, awareness of which might be conscious or intuitive". Tourist destination can be branded just as goods and services are branded and categorized. Morgan \& Pritchard (2001, p. 281) give a good example of how the concept of branding can be built around a tourist destination, as is the case of places like Paris, Venice, San Francisco or the French Riviera. This last destination is a good example of how a tourist brand can be translated into other cultural and geographical contexts: the English Riviera, the Mexican Riviera, the Croatian Riviera and, recently, the Egyptian Riviera, for example.

Branding, according to Anholt (1999, cited in Morgan \& Pritchard, 2001, p. 215), is "the creation of a distortion field in the mind of the consumer which interferes with his or her sense of value so that he or she is prepared to pay more for a product than its intrinsic worth would suggest". In this way, a consumer is willing to pay an extra price for a specific product. The value of a specific brand depends on "being different" and attracting the consumer's attention, so that they remember not only the product, but especially its name. Three criteria are normally established in international marketing for a name to be effective and successful: distinctive, 
memorable, and short. Spain, as a tourist destination, meets these criteria as a name, and, as I shall discuss further below, it also meets some of the brand's core values: credible, plausible, durable and deliverable. Policy makers, marketers and creative teams should join efforts with translators to make a wise and effective use of branding as a tool to establish cultural and emotional links between target consumers and destination, in order to appeal to the consumer and develop consumer loyalty. As Klein (2000, p. 146) puts it, it is often a matter of "brands, not products [...] if brands are about 'meaning', not product attributes, then the highest feat of branding comes when companies provide their consumers with opportunities not merely to shop but to fully experience the meaning of their brand".

So what is Spain's image as a brand name in the globalized world over the last few years? According to a series of interviews and surveys carried out by El exportador (2002) (a specialized journal published by ICEX, the Spanish Institute for Foreign Trade), although Spain's image abroad had improved enormously over the last few years, Spain was still a stereotypical and badly perceived "made in", and there was a huge difference between Spain's real situation and how the country was perceived abroad. In my view, such perceptions continue to be valid today. Just as positive perceptions help countries to promote their companies, services and products, certain brand names have helped some countries to develop a positive image. Some top executives believe that the image effect generated by companies and brands for a given country is more powerful than the other way round. Then it would be desirable to be aware of the importance of a country's image, encouraging translators working for these companies to be more aware and knowledgeable of the image construction process and the relevant role of translators in the process.

In general, there seems to be a great difference between the general positive image of Spain as a brand tourist destination, and a negative -or neutral- image of "made in Spain" products and services. This is sometimes due to an inherited negative image of the country linked both to its former political situation under Franco's dictatorship and to many of the negative stereotypes listed above.

Research shows that this picture does not correspond with Spain's economic, technological and cultural reality at that time and at present (Anuario El País, 2003; Atlas de Le Monde Diplomatique, 2003 and 2013; Noya, 2002). A recent global survey by HSBC bank (2016: online) on the living conditions of expats in different parts of the world, and their overall views on the given destination, shows how some of Spain's main traits have evolved in the last decade. In economic terms, Spain ranks 42 (out of a total of 45 countries), right after Egypt and the Philippines. The survey indicates that Spaniards are unpunctual and can sometimes be harsh. It also points out that the bureaucracy is still a serious drawback and that Spain is in general a 
patriarchal society. However, in experience (lifestyle and quality of life), Spain ranks second in the world, after New Zealand.

In tourist terms, Spain is certainly a superpower, and considered a supra-brand. Morgan \& Pritchard (2001, p. 282) set the beginning of the ongoing construction of Spain as a supra-brand in the early 1980s, mentioning the different criteria a destination has to meet in order to develop a durable brand image which earns it a "supra-brand" status: credible, deliverable, differentiating, conveying powerful ideas, attractive for trade partners, and resonating with the potential tourist. Once again, the interlinguistic and intercultural expertise of the translator can play a powerful role in the build-up of this set of criteria, not only in terms of the pure translation, but also in terms of the persuasive and informative functions of the advertising text.

Spain as a whole is the supra-brand, maintaining an overall general advertising policy of the country as a destination with a varied and differentiated tourist offer, from the sun and beach product to culture, heritage and cuisine. By meeting the "differentiating" factor Spain ensures itself a place in the tourist market as a "unique" destination that "has something that connects with you", as some interviewed English-speakers have put it. While Spain is the supra-brand, the main Spanish cities (Madrid, Barcelona, Seville, Granada) and tourist regions (Andalusia, the Canary Islands, Catalonia) would be the sub-brands.

Spain's successful positioning as the third tourist destination in the world is due in great part to the main different institutional international advertising campaigns carried out over the last three decades. Also, and as part of such positioning, several regional governments (Andalusia, Catalonia, Asturias, the Canary Islands) have adhered to some of those campaigns, in an effort to contribute to the establishment of Spain as a supra-brand, and especially to promote and develop their own image as sub-brands, all of them obtaining very positive results. A good example of this would be the central Spain region of Castile-La Mancha, which in 2005 successfully exploited the 400th anniversary of the first edition of the world-famous Don Quixote of La Mancha to promote tourism in the region, and has repeated the strategy in 2016 with the 400th anniversary of the death of its author, Cervantes.

\section{Case study of advertisements for institutional Spanish tourism: the slogan, ( $r$ )evolving image}

Five major different slogans have been used by Turespaña in its international advertising campaigns from 1984 to 2010/2011. In general, we could say that the slogans used in those campaigns show a progressive, well-structured medium-term strategy aimed both to extend the country's tourist offer to other products (cultural sites, Spanish cuisine, rural tourism) and destinations around the country, and to try 
and develop an image of Spain as a quality and varied tourist destination. All the texts used in these campaigns are professionally crafted, and make an increasingly better use of images and iconic elements to attract the potential consumer's attention.

Turespaña has been gradually introducing new tourist products in an attempt to broaden the image of Spain as a sun and beach destination, extending the tourist offer to cultural and cuisine products, rural tourism, and areas unknown to the visitors. Since 1984, Turespaña has developed five main tourist advertising campaigns. We will deal here with the first four ones. The last campaign, with the slogan “I need Spain" (Heras Marcos, 2014, p. 33), was introduced in 2010.

The first campaign, with the slogan "Spain, everything under the sun", was introduced in 1984, based on the concept of sun and sand holidays for the mass market. The campaign helped to start building brand values for Spain as a tourist destination. The main success in this sense was the introduction of the Miró logo as a trademark for Spanish tourism. Miró designed the logo in 1983 (the year of his death), as a piece of modern contemporary art, and it both symbolizes Spain's past and looks to the future, incorporating representations of Spanish culture icons: the sun (yellow and red), the stars, and the bullring (black). Everything revolves around (under) the concept of sun, obviously implying the idea of sun and sand holidays as the main offer, with a minor presence of art and historic examples. The campaign lasted until 1990, with minor changes in the slogan.

In 1991, the Spanish Tourist Board decided to seriously diversify the country's tourist offer through a new campaign under the tremendously successful slogan "Passion for life". The slogan encompassed a common term for defining "Spanish-ness" ("passion") and a quest for a lifestyle that implies enjoyment, adventure, discovery, cultural and historical tradition. The slogan was adopted at a key moment in recent Spanish history, with the hosting of the summer Olympic Games in Barcelona and the Universal Expo in Seville. Both events were held in 1992, which posed an extraordinary opportunity to show the Spanish uniqueness to the world.

From the intercultural point of view, the "Passion for life" slogan was a sure winner, delivering a message of a country with an evolved image, a traditional country with a growing level of development, focusing not simply on a particular tourist product, but on a wide choice of possibilities, which included friendly and hospitable people ${ }^{4}$. Most importantly, it conveyed an emotional link with potential tourists. It is worth

$4 \quad$ It is interesting how some "alleged" stereotypes are used in a negative versus positive way. A few years ago, the US state of Texas launched a tourist campaign with the slogan "Visit a country where the natives are friendly and the language barrier is easily overcome". 
mentioning here that this was specially taken into account with English-speaking target countries such as the UK, which had been rated in different surveys as "dull" or "boring" countries. The introduction of such emotional motto was surely a good way (and a challenge) to scare away said stereotype. This slogan meant a quantum leap in the establishment of Spain's new image and its development as a brand.

The "Passion for Life" campaign is particularly interesting in its skilful exploitation of single words associated with Spain (soul, olé), which appear in the background of each of the ads while shifting away from negative stereotypes. The "passion" factor was so powerful that, since then, it has been extensively used in many private advertising campaigns and slogans as a catch-word in the international promotion of other Spanish products (cars and wines, for example) and cultural or sports events (such as art exhibitions, and football and tennis matches).

Six years later, in 1997, a new campaign under the slogan "Bravo Spain" was launched, which played on a very successful combination of traditional and modern images. It was a varied campaign, with a very significant promotional budget. According to the World Tourism Organization, at this point Spain had the world's third largest promotional budget for tourism ${ }^{5}$. Spain seemed to have reached its top in several senses: top promotional budget, top tourist destination, top varied tourist offer (the word "Bravo" seems to confirm this fact, as a word used to express appreciation when something is well done).

Morgan \& Pritchard (2001, p. 290) describe in detail the nuts and bolts and the results of the campaign:

The "Bravo Spain" campaign, which replaced that of 1996, was tested in the key markets of the UK, Germany and France, where it was seen positively the word "Bravo" conjured up images of approval -allaying fears in Spain of any negative connotations of its association with bullfighting. Intended to communicate a different, modern Spain, this campaign uses strong, visually impressive images in its television, press and poster executions. In the print ads (which are the backbone of the campaign) the consistent image is of a blurred photograph with a larger, perfectly focused close-up window showing some detail of the photograph. Every region of Spain is featured in the ads, which mix well-known attractions (such as the new Bilbao [Guggenheim] museum) with less-known sites (such as Valencia's new concert hall) and include an interesting copy and a small map [of Spain] indicating the location of the scene in the poster.

As pointed out in another study (Fuentes \& Kelly, 2000), an interesting parallel may

5 With a total promotional budget of more than $\$ 71.6$ million, $43 \%$ of which went to advertising. 
be drawn here with some institutional advertising of two Spanish sub-brands, the Basque Country and Catalonia, designed mainly to consolidate the separate identity of these areas as sites for good investment opportunities. The texts use the concepts of Europe and the Mediterranean (for the latter) as strong selling points. Indirect, or on occasion direct, reference to the negative stereotypes of Spain is deliberately used here too, but in this case it is made to dissociate these two regions from the image of the rest of the State.

In September 2002, Turespaña chose the slogan "Spain marks" to replace "Bravo Spain". The Spanish Tourist Board argued that market surveys indicated that it was necessary to find a new slogan that would add a more emotional and inclusive character to the advertising campaign. Turespaña officials pointed out that the campaign was expected to last for at least four years, and that anything less than that period of time would be considered a failure ${ }^{6}$. It was a very ambitious and expensive campaign, with 16 printed ads ${ }^{7}$ as the backbone of the promotional work (one of them was eventually censored after accusations that it was degrading for women). The ads showed modern, stylish, black and white photographs metaphorically linked (although only in principle) to the "Spain marks" slogan, highlighted in red capital letters, which summarize some of Spain's main symbols and stereotypes: blood, bullfighting, wine, food, flamenco and, of course, passion. The word "passion" appears in most of the ads, thus continuing the philosophy of the former "Passion for life" campaign and strapline. However, in some cases, it is not clear what the term "passion" refers to.

The left hand bottom corner part of the ad contains an inserted colour photograph, Miró's logo, a small map of Spain indicating the scene's location, and some allegedly illustrating text which tries to establish a link between the rest of the graphic elements. Translators should not only focus on the linguistic elements, but also, as Zanettin (2008, p. 23) points out, pay particular attention (especially in the case of tourist promotional texts) to the visual elements: "While the analysis can be focused on the translation of the verbal component, it cannot dispense with an examination of how words interplay with visuals in the co-construction of meaning". Visual elements, and especially images or photographs, are "considered as peritextual elements that should be 'paratranslated"' (Cómitre \& Valverde, 2014, p. 79). Certain Spanish tourist sub-brands, such as Andalusia and Catalonia, would later join the campaign, promoting their regions' main tourist attractions under the umbrella of the same campaign features and the same "marks" slogan (e.g. "Andalucia marks",

\footnotetext{
$6<w w w . e x p a n s i o n d i r e c t o . c o m>$ [3/07/2015].

$7 \quad<$ www.spain.info/Portal/EN/Services/Campaigns/Default.htm> [5/07/2015].
} 
"Catalonia marks", “Galicia marks", etc.).

An aspect that both "Spain marks" and "Andalucia marks" have in common is that they apparently use the same campaign for very different target markets. Here we are confronted with the complex globalization / localization / glocalization issue (Adab, 2000; Jiménez-Crespo, 2013). Some companies have incorporated the localization concept into their advertising: HSBC, one of the world's largest banks, stresses in its ads the importance of localizing products and marketing, under the "Local knowledge" slogan and a series of interesting iconic representations. Its latest campaigns highlight the importance of local knowledge and how this is crucial in doing business globally. Translation is, among others, about the exchange of people, knowledge and culture. The HSBC ads show how the knowledge of culture can be linked to business growth as it facilitates the business operations in a market that may otherwise be alien to the consumer. They have also wisely placed their ads in key locations, such as London's Heathrow International Airport. The campaign, which has been translated into 19 languages (from Maltese to Malaysian) in 76 countries where the bank has branches, is surely a successful way of promoting a global brand. HSBC's ads are so effective that the concept is effectively communicated to local audiences no matter what language is used. Tourist advertising translation is probably one of the areas with the highest level of localization or glocalization. For example, a tourist ad offering sun and sand holidays as the destination's main attraction will probably fail in Australia (where there are superb sunny beaches) or Japan (Japanese tourists usually visit European sites for cultural, shopping or entertainment purposes, but very rarely for sun and beach holidays). This fact reveals the need of conducting comprehensive market research in key international markets and of selecting appropriate target niche markets.

In terms of the globalisation debate, the Indian anthropologist Appadurai (1990) suggests that in the current global context, national boundaries no longer define the limits of identity, culture or the media, pointing out that rather than exploring these concepts within national boundaries, the focus should be on how people, culture and ideas flow between specific locations. Interestingly, he points out that cultures change in translation, so that being a Muslim in a Pakistani village may be quite different from being a Muslim in a British town.

From the translation point of view there are certain differences worth mentioning between the "Spain marks" and the "Andalucia marks" advertisements. First, while the former includes a small map of Spain as a locating aid for the reader, the latter shows a map of Europe, which in my view is a wiser strategy and much more helpful, especially for potential target tourists who might need some further explanation of the geographic location of Spain. The "Catalonia marks" one, however, sticks to the region's map only. Second, apart from the official Miró logo, the regional ads contain 
the logos of the respective regional tourist boards, because they are sub-brands themselves and because the promotional campaigns have also been financed by the regional governments. Third, there is a reshaping of the brand name, from "Andalusia" to "Andalucia". Former examples of this would be the repositioning of Seville as "Sevilla" through the 1992 Expo, and, in the mid-90's, the Balearic island of Majorca, which became "Mallorca". Finally, the Andalusian campaign consists of three specific ads based on Turespaña's "Spain marks" campaign originals, aimed at the three most demanded tourist products, namely, sun and beach, golf, and cuisine.

Sometimes the translator has to avoid certain cultural references contained in the original text and has to opt for a neutralization of the information. This is particularly necessary in the case of certain religious or political references, and especially in the case of eating habits, taboos, etc. The ads in the "Andalucia marks" campaign are slightly different, one of them portraying a photo of a serrano cured ham, which in principle would not pose potential cultural problems if the campaign is aimed, as is the case at Western target markets (the USA, Canada, Denmark, Finland, Sweden and Norway). However, the photograph would be culturally inappropriate for Muslim countries, for example. This is a simple but serious example where the translator's cultural competence and his/her advisory role are very useful. While it could be argued that such neutralization would equate to a manipulation of the source text, in my view, this is but a strategy employed by the translator, and a mere act of intercultural mediation.

Another example would be the use of certain formal words that might evoke confusing connotations. Perhaps the best example in the "Spain marks" ads is the use of the word "gastronomy". For this campaign, I carried out an informal reception survey among a sample of 33 native speakers from English-speaking countries (Australia, Canada, Ireland, the UK and the US) from a different cultural background, education level (19 university studies; 6 secondary or vocational education; 3 primary education; 4 no formal education) and age (22-70). Almost half of the interviewees did not even know the meaning of the term. None of them liked the word (e.g. "sounds like I need an antacid!"). Some other comments went in a more reasoned line, such as "I realize in Europe the term refers to gourmet food. But I prefer the word 'cuisine' over gastronomy". This is one of the cases in which a potentially successful advertising idea can fail if the participation of the translator as an intercultural and linguistic expert in the creative process is overlooked.

The "Spain marks" slogan itself seems to be a literal translation from the Spanish "España deja huella" ("Spain makes a mark"). In any case, "Spain marks" is neither a good translation of the expression nor communicates effectively a positive effect, thus failing to convey the required alluring function of advertising, and even 
producing a rejection reaction in the reader. Some of the comments provided by those surveyed proved this point: "Linguistically in English, mark is a noun. The verb would be to make a mark (line, dot, grade), some sort of symbol. Or to denote. Culturally as an American, it doesn't connect", "It is hard to understand what is being communicated", "I don't get the whole 'Spain marks' thing. I don't find it appealing", "I don't get the relationship between the photos and 'Spain marks', what are they selling?", "It sounds painful to me! 'Marks', like leaving you with a scar". There is an obvious pragmatic problem in the wording of the slogan, as it has more negative connotations in English than positive ones: the slogan is not understandable, the message is not conveyed, the expected function is not achieved, and the sought effect is quite the opposite. In a parallel and interesting study carried out by Cómitre \& Valverde (2014), the interviewees also found that the visuals and texts used in this campaign did not match very well. This matches the opinions of those participating in my study, who described some of the image/text combinations used in the campaign as "awkward", "bizarre", "strange", "negative", and even "revolting".

It would appear that the translation work here was not done by a professional translator, or even by someone with a good level of English. The different texts used in the various ads also contain examples of inadequate vocabulary ("when you leave you'll be changed, body and soul") or are not linked with the rest of the graphic or iconic elements properly. Perhaps a possible translation could be something in the line of "Spain's indelible mark / lasting impression".

The photographs chosen for the ads, although they may be stylish and modern, do not seem to be either understood or positively perceived by many of the surveyed people: "I couldn't get what Spain is trying to convey about itself", "Take the first picture, the one of the strapped shoes. Does it denote dance, fashion? My first impression was... whooaa! It looks painful!", "The second picture, is it a girl, boy, child?", "The tooth pick is a mark of defiance and arrogance. In other words, I think that I get the general idea but, please excuse the pun, it misses the mark". Another ad shows a large photograph of a smiling fair boy with a skiing-goggles tan, which is very confusing for the target reader, since the smaller photo shows a view of a rocky beach on the coast of Alicante. People do not wear skiing goggles on the beach, and do not get that tan mark when scuba-diving. Also, the text in the ad talks about " 4,800 miles of coastline". Very few countries in the world still use the imperial system of weights and measures. The US is probably the main country in this group. However, this campaign is also aimed at Scandinavian countries, which, despite their good command of the English language, might not be so familiar with miles. The text goes on talking about "445 blue flag beaches", a term used within the European Union to certify the quality of a given beach. US or Australian tourists, for example, will probably not know what the term stands for, as these countries are not part of 
the Blue Flag beach scheme.

The surprising, but positive fact about the "Spain marks" campaign is that there seems to be a strategy to shift away from the usual sun and beach offer to a wider choice of tourist products. Only one out of the sixteen ads in the campaign refers or promotes sun and sand. The remaining fifteen highlight other aspects of Spain's richness, such as culture, art, architecture, golf, flamenco, Spanish as a foreign language, cuisine, etc.

\section{Intercultural mediation in tourist advertising translation}

Throughout this article I have highlighted the importance of stereotypes, perceptions, image, and cultural references in international tourist advertising. I have also pointed out the relevance of the role of the translator in the conception, creation and development of the advertising campaign. I will now discuss in more detail my views on the role of the translator in this process.

Many authors have talked about the importance of the intercultural competence of the translator. In order to fulfil their role efficiently, it is not enough to be aware of cultural differences, but also of how the source and target cultures view each other. A solid knowledge of the source and target cultures' mutual perceptions and stereotypes will enable the translator to use them in different ways in order to achieve an effective and functional target text. The different elements of a tourist ad cannot be worked out and developed separately. Advertising translation is a mode of constrained translation, where the verbal elements are only a small part of the whole text. If this is the case, then "the translator's intervention could, or indeed should, also affect the visuals" (Fuentes \& Kelly, 2000, p. 241). Such intervention should not only be in line with the tourist's expectations, but also go beyond the needs of the target audience:

It is true that tourist texts often do require considerable "adaptation," situating the activity of tourist translation close to that nebulous border existing in theory between translation and rewriting [...]. The ideal solution would perhaps be to produce specific texts for each target culture (Kelly, 1997b, p. 34).

Frequently, in Spanish institutional advertising there is no source text (ST), but just a general target text (TT) aimed at different markets, without taking into account the potential cultural barriers of the TT reader's expectations. Translators are all too often left out of the TT production process, and overlooked as an intercultural expert and mediator. The consequence is that the TT may not fulfil its functional purpose and therefore the potential success of message reception in the target 
culture will not be achieved.

In the case of the "Spain marks" campaign, the TT clearly follows a literal application of both linguistic and cultural criteria, based on the assumption that such "mark" would be culturally and linguistically understood and accepted in the different markets. Reality shows a different panorama. In some cases, the pursued "branding of Spain" suggests branding the people, like cattle; in others, it implies some sort of permanent mark or scar.

The problem with commissioning TT production fully to marketing specialists, ignoring the mediation work of the translator, is that creative teams and art directors may come up with a great advertising idea, but often do not have the necessary linguistic and cultural competence to communicate the essence of the message. As Adab (2000, p. 225) puts it, "analysis could be expected to show evidence of some degree of adaptation of culture-specific connotative values in order to preserve the intended text impact". Hence the need to incorporate translators to creative teams from the early stages of the marketing and promotion process of the campaign. Translators will have to take active part in the creative process, assessing potential implications and the level of communicative effectiveness, and determining what degree of cross-cultural adaptation is necessary.

Some tourist destinations seem to have taken a careful approach to different target markets. In this sense, Norway's official tourist website ${ }^{8}$ has different graphic contents and slogans depending on the target market: "Norway, a pure escape" (UK/Ireland), "Norway, the perfect change of place" (US/Canada), "Harmony, enrichment, magnificent, friendly, genuine, well organised" (international version). This last slogan also encompasses some of the main positive stereotypes of the country's perceived and projected image. Belize is another good example. Its website ${ }^{9}$ in English advertises the country as "Mother Nature's best kept secret", whereas the Spanish slogan focuses on a different target niche: "El paraíso de los aventureros" ("Adventurer's Paradise").

Some authors, like Adab (2000), recommend that translators should be included early on in the process of producing the source language $(\mathrm{SL})$ advertising message (a recommendation that I fully adhere to). She also recommends giving "clear information to the ST producer and to the translator about the nature of the

\footnotetext{
<wWW.visitnorway.com> [17/01/2014].

$<$ www.travelbelize.org > [17/01/2014].
} 
product" (in the case of Spain: sun and beach, cuisine, culture, people, tradition, modernity, etc.) and "the qualities associated with the product for the target culture ( $\mathrm{SL}$ or $\mathrm{TL}$ ) (it is assumed that market research will have identified the profile of the target reader, whatever the language community)" (Adab, 2000, p. 233). Although I agree with Adab here, I do not think this is the case with the "Spain marks" campaign, since there are differences between the expectations of the target reader/consumer and the set of values, traditions or products being offered or exploited.

\section{Conclusion}

Marketing experts usually carry out extensive pilot studies and surveys before presenting a campaign to the client. However, the focus seems to be put mostly on the product or the campaign, sometimes missing the real target, namely, the reader/consumer. Receivers are the cornerstone of any advertising campaign, and reception studies should be integrated in the marketing process of tourist advertising. Translators should also be well aware of this fact, as recent studies prove (Fuentes, 2001 and 2005; Nobs, 2003). In this sense, efficient and successful cultural and linguistic mediation needs to be achieved through professional, skilled inception, development and delivery of the promotional tourist text, regardless of the medium used to convey it. I fully agree with Soto (2013: 235), who makes specific reference to the case of Spain: "We [translators] must consider tourist translations as an element of mediation and relationship between the tourists and the places that they visit and we must reflect on the necessity of quality tourism translations in Spain". Equally important is, as mentioned above, to adapt texts to the target tourist expectations and, as stated by Durán (2008), quality norms.

Translation researchers and academics are increasingly adopting an interdisciplinary approach, and extensively read and consult journals and publications from different areas of knowledge, obtaining insights from different perspectives and fields of work. However, such approach seems to have worked so far (as can be seen from examples such as the campaigns analysed above) in one way only, and marketing experts and campaign decision-makers have not seriously weighted the enormous importance of creating, developing, and delivering quality promotional tourist campaigns. It is therefore both desirable and necessary that marketing experts, ST initiators and policy makers, among others, consider and incorporate professional translators and translation researchers' considerations and findings into the process. Mutual feedback can be nothing but extremely positive and beneficial for both sides, especially in such a dynamic field as advertising. This is particularly relevant in the case of countries and territories whose main source of income depends heavily on tourism, such as Spain and its different regions, which need to 
create and keep a positive brand image.

\section{About the author}

Adrián Fuentes Luque is Associate professor in Translation at the Universidad Pablo de Olavide (Seville, Spain). His main fields of interest include audiovisual translation, the history of translation, translation of tourist and advertising texts, translation of humour, and institutional translation. He is the editor and contributing author of the first volume on translation and tourism (La traducción en el sector turístico), and numerous articles and book chapters: "Institutional Audiovisual Translation: A (Shop)Window to the World", "La historia de la traducción audiovisual en Latinoamérica: aproximación a su investigación", "A collaborative multimodal working environment for the development of the instrumental and professional competences by trainee translators: an innovative teaching experience", and "An Empirical Approach to the Reception of AV Translated Humour", among other publications.

\section{Article history}

Paper received: 4th May 2016

Paper received in revised form and accepted for publication: 14th October 2016

\section{References}

Adab, B. (2000). Towards a More Systematic Approach to the Translation of Advertising Texts. In A. Beeby, D. Ensinger \& M. Presas (Eds.), Investigating Translation (pp. 223-234). Amsterdam/Philadelphia: John Benjamins Publishing Company.

American Marketing Association (2016). Dictionary.

$<$ https://www.ama.org/resources/pages/dictionary.aspx?dLetter=l> [5/10/2016].

Andreu, L., Bigné, J. E. \& Cooper, C. (2000). Projected and Perceived image of Spain as a Tourist Destination for British Travellers. Journal of Travel and Tourism Marketing, 9(4), 4767. 
Anholt, S. (2000). Nation-brands of the twenty-first century. Journal of Brand Management, 5(6), 395-404.

Appadurai, A. (1990). Disjuncture and Difference in the Global Cultural Economy. In M. Featherstone (Ed.), Global Culture: Nationalism, Globalisation and Modernity (pp. 295-310). London: Sage.

Atlas de Le Monde Diplomatique (2003). Valencia: Ediciones Cybermonde.

Atlas de Le Monde Diplomatique (2013). Valencia: Ediciones Cybermonde.

Cómitre Narváez, I. \& Valverde Zambrana, J. M. (2014). How to translate culture-specific items: a case study of tourist promotion campaign by Turespaña. JoSTrans. The Journal of Specialised Translation, 21, 77-111.

Durán Muñoz, I. (2008). "La traducción turística de calidad: una necesidad indudable en la España de hoy." VII Congreso Anual Internacional de la Asociación Europea de Lenguas para Fines Específicos (AELFE): Investigación y enseñanza de lenguas para fines específicos: nuevos retos, nuevos contextos. 18-20 September 2008, Murcia. (pp. 380-395).

El País (2003). Anuario El País. Madrid: PRISA.

Fuentes Luque, A. (2001). La recepción del humor audiovisual traducido: estudio comparativo de fragmentos de las versiones doblada y subtitulada al español de la película Duck Soup, de los Hermanos Marx, PhD thesis. Granada: Universidad de Granada.

Fuentes Luque, A. (2005). La traducción de promoción turística institucional: la proyección de la imagen de España. In A. Fuentes Luque (Ed.), La traducción en el sector turístico (pp. 5992). Granada: Átrio.

Fuentes Luque, A. \& Kelly, D. (2000). The Translator as Mediator in Advertising Spanish Products in English-Speaking Markets. In A. Beeby, D. Ensinger \& M. Presas (Eds.), Investigating Translation (pp. 235-242). Amsterdam/Philadelphia: John Benjamins Publishing Company.

Heras Marcos, A. (2014). La promoción turística de España: turismo de calidad y Marca España. Degree in Tourism. Final year dissertation. Segovia: Universidad de Valladolid. <http://uvadoc.uva.es/bitstream/10324/5377/1/TFG-N.16.pdf> [8/9/2016].

HSBC Bank. (2016). Expat Explorer. Achieving Ambitions Abroad.

$<$ https://www.expatexplorer.hsbc.com/survey/files/pdfs/overallreports/2016/HSBC_Expat_Explorer_2016_report.pdf> [1/10/2016].

Hu Y. \& Ritchie J. (1993). Measuring Destination Attractiveness: A Contextual Approach. Journal of Travel Research, 32(2), 25-34.

Instituto Español de Comercio Exterior (Ed.). (2002). España. La marca. El Exportador, 49, 6-17. 
Jiménez-Crespo, M. A. (2013). Translation and Web Localization. New York: Routledge.

Kelly, D. (1997a). Prensa e identidad nacional. La imagen de España en la prensa británica. PhD thesis. Granada: Universidad de Granada.

Kelly, D. (1997b). The Translation of Texts from the Tourist Sector: Textual Conventions, Cultural Distance and Other Constraints. TRANS, 2, 33-42.

Klein, N. (2000). No Logo. Toronto: Vintage Canada.

Lamo de Espinosa, E. (1996). La imagen de España en el exterior. Leviatán. Revista de Hechos e Ideas, 66, 5-38.

Morgan, N. \& Pritchard, A. (2001). Advertising in Tourism and Leisure. Oxford: ButterworthHeinemann.

Nobs, M. L. (2003). Expectativas y evaluación en la traducción de folletos turísticos: estudio empírico con usuarios reales. PhD thesis. Granada: Universidad de Granada.

Noya, J. (2002). La imagen de España en el exterior. Estado de la cuestión. Madrid: Real Instituto Elcano de Estudios Internacionales y Estratégicos.

Seguinot, C. (1994). Translation and Advertising: Going Global. Cultural Functions of Translation, monographic of Current Issues Language and Society, 1(3), 249-266.

Soto Almela, J. (2013). La traducción de términos culturales en el contexto turístico españolinglés: recepción real en usuarios anglófonos. Quaderns, Revista de traducció, 20, 235-250.

Zanettin, F. (2008). Comics in Translation: An Overview. In F. Zanettin (Ed.), Comics in Translation (pp. 1-32). Manchester: St. Jerome Publishing. 